\title{
The Social Body of Muslim Women
}

\section{An Analysis of Hijab and Beauty}

\author{
Refti Handini Listyani \\ Universitas Negeri Surabaya \\ Surabaya, Indonesia \\ reftihandini@unesa.ac.id
}

\author{
FX Sri Sadewo \\ Universitas Negeri Surabaya \\ Surabaya, Indonesia \\ fsadewo@unesa.ac.id
}

\author{
Martinus Legowo \\ Universitas Negeri Surabaya \\ Surabaya, Indonesia \\ mlegowo@unesa.ac.id
}

\begin{abstract}
This research examines beauty myth of Muslim women using a literature review approach. Several theories are employed in this research including the theory of sociology of body, gender perspective and the concept of sexuality. Results indicate that the women are veiled as if they are competing to look as attractive as possible according to their own characteristics. Hijab which can be a symbol of liberation from beauty standards now is not separated from the attributes of beauty. This study showed women with veils still cannot be separated from the myth of beauty. Religious norms that are compromised with modernity and commercial do not dispel the myths. The implications of this research are this study is expected to contribute information and enrich the repertoire of social science especially sociology also for the development of research on women body, hijab and beauty.
\end{abstract}

Keywords - muslim women; body; hijab; beauty

\section{INTRODUCTION}

Increased sociological concern for the body is preceded by the emergence of a culture of consumption in the second half of the 20th century, which highlights the body as an object of exhibition, a display to be designed, carved, and shaped through the rules of "beauty", clothing and lifestyle. Two important aspects of this new relationship between body and self are first, the appearance of the body includes an expression of individuality and personal identity. Second, the body rules include strategies used to maintain, create, and control body appearances such as diet, exercise, cosmetic surgery, clothing [1].

Through a beauty clinic, the body is commodified. Beauty is power because it can be used to create social distinctions, which indicates the position of a particular class status. By being beautiful, then someone will get more convenience than the ugly.

Female beauty is constantly directed and controlled to make the position of women become weak, even to the body and its own beauty. Looking at these trends, the beauty industry captures and exploits women's weaknesses as a promising business potential by presenting hospitality-based beauty clinics. Beauty Clinic offers skin care and beauty care services by providing various beauty products and modern treatments that strive to meet the needs of beauty so that it can support the appearance [2]

The body is also very much related to beauty, the way the body's presentation can be said has become part of a regime of beauty when there is social value in it cultural desires, dreams to be beautiful. The desire for the dream of beauty become part of a cultural value that when strengthened will become a regime. In culture consumers, the female body is constructed through a series of norms and values, so that there hegemony of body beauty concept [2].

TABLE I. PREVIOUS RELATED RESEARCH

\begin{tabular}{|l|l|c|l|}
\hline No. & \multicolumn{1}{|c|}{ Title } & $\begin{array}{c}\text { Theory/ } \\
\text { Methode }\end{array}$ & Finding \\
\hline 1. & $\begin{array}{l}\text { Hijab } \\
\text { Fashion } \\
\text { Industries } \\
\text { 'Unveiled' } \\
\text { (Farhad, }) \\
\text { [3] }\end{array}$ & case study & $\begin{array}{l}\text { the media and the hijab are } \\
\text { domestic factors when } \\
\text { examining on femininity, soft } \\
\text { tesettur, and on Turkey trying to } \\
\text { sell their tesettur apparel } \\
\text { through fashion marketing tools } \\
\text { on the 'cheerful hijab.' }\end{array}$ \\
\hline 2. & $\begin{array}{l}\text { Meanings } \\
\text { of modesty } \\
\text { and the } \\
\text { hijab } \\
\text { amongst } \\
\text { Muslim } \\
\text { women in } \\
\text { Glasgow, } \\
\text { Scotland } \\
\text { (Siraj, } \\
\text { 2011) [4] }\end{array}$ & $\begin{array}{l}\text { snowball } \\
\text { sampling } \\
\text { technique, } \\
\text { linguistic, } \\
\text { hermeneutic }\end{array}$ & $\begin{array}{l}\text { Women saw the hijab not as a } \\
\text { marker of exclusion but as a } \\
\text { source of empowerment. }\end{array}$ \\
\hline 3. & $\begin{array}{l}\text { Hijabers: } \\
\text { How } \\
\text { young } \\
\text { urban } \\
\text { muslim } \\
\text { women } \\
\text { redefine }\end{array}$ & $\begin{array}{l}\text { instagram } \\
\text { observation/s } \\
\text { emantic }\end{array}$ & $\begin{array}{l}\text { The Hijabers are critical of } \\
\text { conventional perceptions of } \\
\text { religious values and norms, and } \\
\text { yet they decide that a part of } \\
\text { them wants to celebrate their } \\
\text { religiousness as well as their } \\
\text { ability to play with the tools }\end{array}$ \\
\hline
\end{tabular}




\begin{tabular}{|c|c|c|c|}
\hline & $\begin{array}{l}\text { themselves } \\
\text { in } \\
\text { Indonesia } \\
\text { (Beta, } \\
\text { 2014) [5] }\end{array}$ & & $\begin{array}{l}\text { they have at their disposal to } \\
\text { express their modesty and } \\
\text { youthfulness. }\end{array}$ \\
\hline 4. & $\begin{array}{l}\text { Hijab and } \\
\text { the Malay- } \\
\text { Muslim } \\
\text { Woman in } \\
\text { Media (N. } \\
\text { Hassim, } \\
\text { 2014) [6] }\end{array}$ & $\begin{array}{l}\text { Gratifications } \\
\text { Theory, } \\
\text { Structuration } \\
\text { Theory }\end{array}$ & $\begin{array}{l}\text { Change in global political } \\
\text { structures and change in local } \\
\text { largely influenced the } \\
\text { representation of the Malay- } \\
\text { Muslim women in Malaysia. }\end{array}$ \\
\hline 5. & $\begin{array}{l}\text { Unfolding } \\
\text { the Modern } \\
\text { Hijab: } \\
\text { From the } \\
\text { Colonial } \\
\text { Veil to } \\
\text { Pious } \\
\text { Fashion } \\
\text { (M. } \\
\text { Woldesem } \\
\text { ait, 2013) } \\
\text { [7] }\end{array}$ & $\begin{array}{l}\text { individual } \\
\text { interviews, } \\
\text { focus groups, } \\
\text { surveys, } \\
\text { and } \\
\text { observations }\end{array}$ & $\begin{array}{l}\text { Establishing an agreement or } \\
\text { balance between piety and } \\
\text { fashion/ethics and aesthetics in } \\
\text { veiling is significant for } \\
\text { contemporary urban residents } \\
\text { of Amman. }\end{array}$ \\
\hline 6. & $\begin{array}{l}\text { Beauty } \\
\text { Premium } \\
\text { and Halal } \\
\text { Cosmetics } \\
\text { Industry } \\
\text { (Saqib Ali, } \\
\text { et.al., } \\
\text { 2016) [8] }\end{array}$ & $\begin{array}{l}\text { consumer } \\
\text { behaviour }\end{array}$ & $\begin{array}{l}\text { Muslims are bound to religious } \\
\text { requirements in every sphere of } \\
\text { life, including cosmetics, } \\
\text { therefore, there is a big scope } \\
\text { for halal cosmetics industry to } \\
\text { flourish and earn the profit. }\end{array}$ \\
\hline
\end{tabular}

Balsamo in The Body Beautiful: Symbolism and Agency in the Social World, notes that the body becomes a site where women, consciously or unconsciously, receive the outstanding meaning in popular culture about ideal beauty. The female body is present to present a site, a dominant advertising billboard to the cultural significance of the female body in postmodernism. Douglas argues, if the body is a "text" on which it is written social meaning, then the common vocabulary, a common set of symbols, is needed to decipher their meaning [2].

\section{RESEARCH METHOD}

The type of research used is the library (library research), which collects data or scientific papers related to the object of research or the collection of data that is literary. Data analysis in this literature research is content analysis (content analysis) is research that is in depth discussion of the contents of a written or printed information. The data used in this research is secondary data. According to Taylor, source selection is based on four aspects namely: First, provenance (evidence), namely the author's credentials and evidence support; Second, objectivity, i.e. whether the perspective idea of the author has many uses or disadvantages; Third, persuasiveness (degree of belief), i.e. whether the author belongs to a group of people who can be believed; and Fourth, value (contributive value), i.e. whether the author's arguments are convincing, as well as having contributed to another significant study.

\section{RESULT AND DISCUSSION}

\section{A. Women Body}

Body and beauty become the regime of values of desire. The body is constructed into a tool to support the appearance, including the control over the body and the aesthetic dimensions of the body. The body is available to get the ideal image of a young, healthy, and beautiful. Perception about the body that can and can be done by someone to be more aware of the outward appearance and body presentation [2].

When someone presents themselves in public, then it has become a picture of an arena that shows a superior existence than its competitors, so as to be a role model in the social world. Here the body is used as an arena. In Gender, Body Politics, and The Beauty Economy in China, Yang said that the body also becomes the vehicle of new pleasures and experiments of the self [2].

The body is deliberately exhibited in the public sphere to be viewed based on the values that have been believed by society. A person can choose and determine his identity construction based on what he consumes. When the text is built, then the meaning will become a distinction. In that context, the body becomes an arena of competition that can mutually tear down and reinforce each other. Arena is also a part of politics, in which there is interaction space as well as competition space [2]

\section{B. Muslim Women and Hijab}

At first, the movement or idea of Islamic feminism sought to revise family law and rejected hijab and in house seclusion. They legitimize the call for education and work for women by developing the example of women in early Islam.

Hijab and veils are a controversial issue when it comes to the probation of Muslim women in various countries. While some Muslim societies consider hijab as the obligation and command of Allah embodied in the Koranic Scriptures, some other Muslims and non-Muslims as well, especially Westerners consider hijab a symbol of the oppression of Muslim women and the backwardness of Islamic societies that have no relevance in the present, as expressed by Muslim feminist Leila Ahmed.

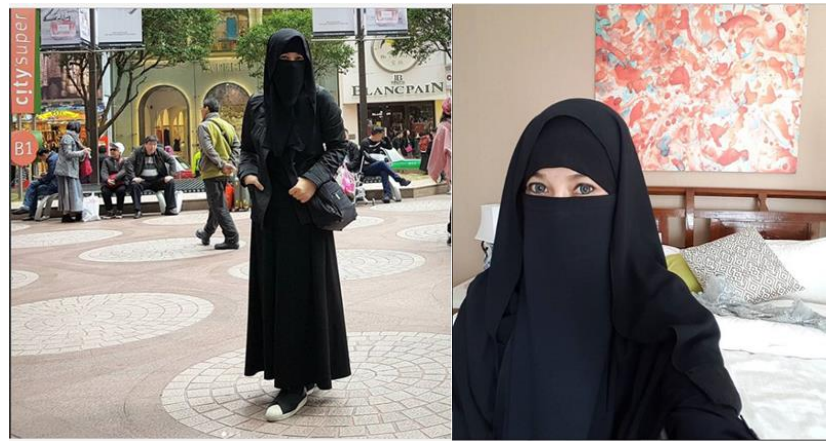

Fig. 1. Appearance of muslim women with niqab on social media (source: https://www.instagram.com/diananurliana/)

Asghar Ali Engineer expressed his opinion that the use of veils and veils is more a socio-cultural practice than purely 
religious. Traditional Muslims have always reasoned that the veil is a Quranic injunction and the offending woman has committed a serious offense against Islamic law. Furthermore, this dress code application contributes to different treatment between women and men because men are treated the other way around.

Qasim Amin's idea of women shows a common thread that connects for the first time the emancipation of women in the Islamic world, especially the renewal of women's rights in Muslim societies. Amin's main idea is not to dismantle and abandon the hijab norms outlined by the teachings of religion, but to restore the true form of hijab (hijab syar'i), as the sacred texts of religious teachings require.

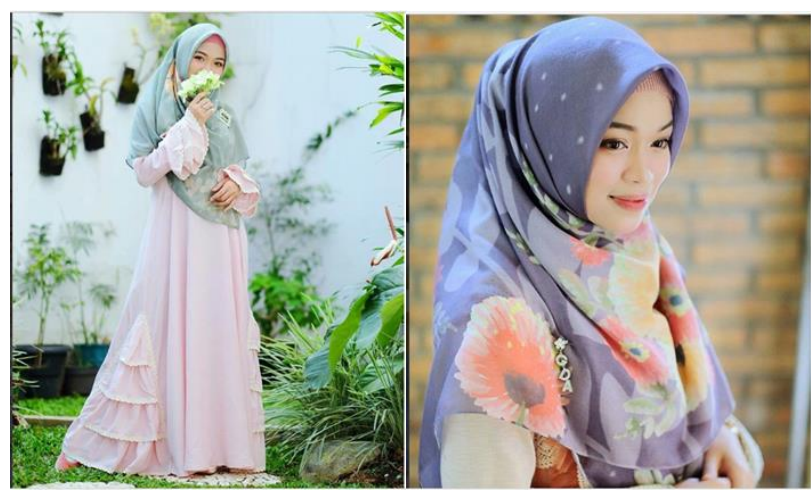

Fig. 2. Appearance of muslim women with hijab syar'i on social media (source: https://www.instagram.com/gdaghaida/)

Hijab has three dimensional concepts, hijab is visually meant to hide something from view. In the spatial sphere, hijab means separating, limiting, and setting up the threshold. Furthermore, from the ethical aspect, hijab is used to indicate that an object can belong to a prohibited domain. Hijab as one form of Islamic symbol and the form of modern muslim modernity is characterized by the rise of muslim identity in Indonesia in response to the development of popular culture of East Asia as well as America. At this stage, the Indonesian middle class is then faced with a wide range of options for adoption.

Hijab as one form of Islamic symbol and the form of modern muslim modernity is characterized by the rise of muslim identity in Indonesia in response to the development of popular culture of East Asia as well as America. At this stage, the Indonesian middle class is then faced with a wide range of options for adoption.

According to Fatima Mernissi, hijab has become an institution contained in verses of Quran, namely QS 33:53. Hijab also has three dimensional concepts, hijab is visually intended to hide something from view. In the spatial sphere, hijab means separating, limiting, and setting up the threshold. Furthermore, from the ethical aspect, hijab is used to indicate that an object can belong to a prohibited domain. This aspect includes ideas from a world that is not palpable. Hijab also not only signifies the separation of men and women, but also between women and God, such as the statement "hijab which is God's rule intended to separate women from men, from The Prophet, and also from God.
Furthermore, if women's bodies are accepted as representative of society, then protecting women by enveloping them and closing them from the outside world has echoed society to close and protect them from Western influence. So with the existence of hijab, women have incarnated into the discourse of exile. Hijab as the identity of Muslim women discouraged to be one of the new attributes of beauty [9].

The concept of women's beauty today in the modern era is increasingly widespread with the emergence of new images and trends of Muslim women's groups. This group displays a picture of a beautiful figure with the use of hijab or veil on women displayed in various media. Both in mass media (magazine, television, advertising) and social media (facebook, instagram, twitter and blog). Muslim women and fashion trends have contributed in shaping the concept of beauty today. The picture of ideal Muslim women arose by displaying the identity of Muslim women are very main, namely Muslim clothing and hijab (fashion) [10].

One form of rejection of women's autonomy is through the process of segregation and segregation, commonly referred to as hijab. Western feminists regard this as a symbol of the backwardness of muslim women. But social facts show that the hijâb phenomenon contains very deep social and political content. It represents symbols such as freedom, honor, simplicity, identity, and also resistance to Western values and westernization [11].

According to Wendy Chapkins, such beauty offered will change the shape of a person's face and body into what one wants to image a cosmetics brand or a beauty program [12]. While in research Karen E. Washburn, it was also stated that the hijab is part of the pop commodity. Even through his research obtained on the basis of three profiles of Javanese women (as the subject of his research), Washburn derives two meanings of the veil as follows [13]:

1. The form of symbol of identification of Muslims by means of various meanings

2. Personal meaning that has no special meaning, but it can bring discrimination against women, but some are interpreted as a means of self-control

3. Form of personal and total transformation

Sociologically, the use of veil in a society, at least also becomes a meaningful symbol, which can distinguish the social identity and cultural representation of each individual or community of its users. In a symbolic context, the veil becomes a marker in the form of a symbol of religious identity, ethnicity, gender and social status, as well as part of how to communicate identity verbally [13].

If it is based on the social identity of Stuart Hall, then the current use of veil is not merely as a representation of cultural identity rooted in religious traditions but also as a group identity, which has a common value in a community. In this case, the veil can also have meaning that depends on a mixture of profane values and the growing emotional bond within a group or community [13].

The veiled woman occupies her position in a new facial capitalism. It begins with a picture of a debate between 
traditional Muslim scholars and Muslim feminists about whether the hijab is an Islamic duty. This illuminates the importance of space, as the practice of hijab is heavily involved and embedded in spatial practice shaped by the local Scottish context. This new form makes all things commercially available. In this case the hijab becomes one of the signs of a form of commodity that can be consumed and can be seen by anyone. Siraj reveal that women in the economic side of his body is used in various activities that become a social picture. According to Wahidah, woman with hijab produced into commodities to be traded through advertising media that seems feasible to be consumed by society. The ad is shifting from function to exchange rate [14].

In the case of hijab commodification, advertisers present a hijab used to strengthen the delivery to the community. Hijab that was sacred, became a commodity to answer the challenge of the era of capital and began to be slowly constructed into a new modification. This continues to be repeated to cause hegemony of desacralization of hijab. Kitiarsa explain that commodification does not aim to produce new religious forms and movements that are contrary to previous religious beliefs and practices, but commodification will place the hijab as a spiritual fungi of religion as goods through religious functions into commodities worth consuming in society [1].

\section{Beauty Myth of Muslim Women}

According to Foucault, the female body is considered "other". That is, the female body is considered different from the male body. Women have certain body parts that are more prominent than men, such as breasts, hips and buttocks. This is what then makes the female body the target of exploitation. Parts of his body that are considered different from this man, are considered to be selling. So no wonder, the female body is often used as a visual object by media actors, especially advertisers [15].

In relation to politics, Foucault's body definition in Discourse, the Body, and Identity says that the body is a very easily formed phenomenon can be embedded with various kinds and turn it into a form of power. Whereas in the context of social standing, it is said that the body in modern society is one of the main factors of self and social position [2].

The existence of a thriving beauty myth, there will be demands for the appearance of attractive, beautiful and fashionable with a variety of apparel and cosmetic modes offered, this will then lead women to become more consumptive. Muslim women's self-identity is in the social construction created by the capitalists because they are aware that clothing, hijab to cosmetics is a commodity.

Roland Barthes, semiotic expert and structuralism, reveals that modern society has been surrounded by myths in every culture of everyday life. Based on Suhanggono statement that "beauty elements such as makeup and fashion are also penetrated into the Islamic world, the beauty myth also affects some Muslim women who live in the Islamic world". If the previous word pretty much labeled on women non jilbab, where beauty is emphasized on the skin, face, stomach, chest and buttocks, the concept now seems to have been widespread. The emergence of new images of the beautiful figure of the hijab in various media make researchers then assume that Muslim women also have a contribution in shaping the concept of beauty today [9].

The internet as a myth producer has the power to create a new picture of the ideal woman. The picture of the ideal female version of the Muslim began to appear, with the Muslim identity, the hijab. So the potential of beauty myths also hit the Muslim women with hijab. Hijab today is not only a religious symbol but also as a culture and lifestyle. Mulyati states that Muslim women today are trying to apply between religion and lifestyle into their lives [9].

Internet (Muslim fashion blog) as a creator of myth through hypes/furor made it, has managed to bring a veil / hijab as an object that is ideological, so it is not neutral anymore. Social media is also a place where beauty myths can be produced and consumed [10].

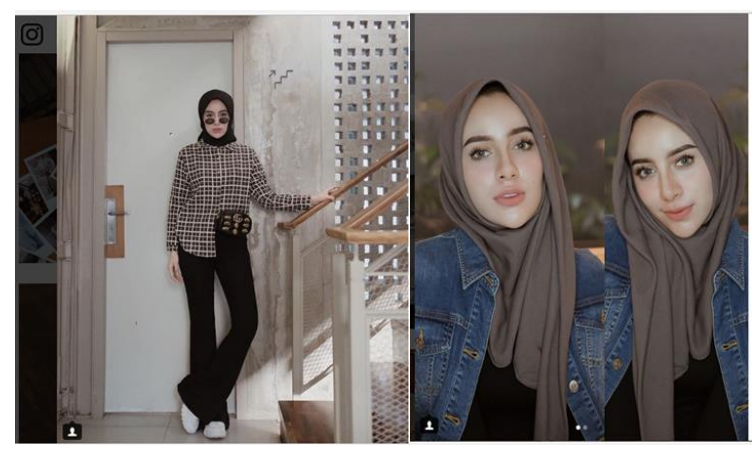

Fig. 3. Appearance of muslim women with modern hijab in social media (source: https://www.instagram.com/aghniapunjabi/)

Beauty pageant in Muslim fashion blog can be classified into 3 big concept of Munfarida property. The first, spiritual beauty (inner beauty) consisting of a beautiful religious, calm and pleasant. Most women who wear Muslim clothes (hijab) feel confident that he is a Muslim better than ever and feel beautiful with him. The beauty desired by women, actually raised from the patriarchal culture in which there is submission in it, beauty must remain based on the blessing and pleasure (pleasure) of male partners. There is the submission of women and the power of men in order to form the concept of female beauty as how we know from the word "ridho of husbands" [9].

Second, the beauty of ethics (inner-outer beauty) consisting of beautiful feminine, beautiful 'free' and beautiful honorable. The use of feminine objects encourages Muslim women to mimic the beauty of a Barbie doll that is recognized as a beauty icon. The beauty of the use of hijab that duplicates the beauty of the dolls is proof that the use of hijab indicates patriarchal symbols.

Third, the beauty of the body (outer beauty) consisting of beautiful luxury and care. Beauty in this setting is lavish with the use of goods and symbols of luxury. Contrast with the Islamic discourse that advocates simplicity.

The results of Dina's study on "hijab", "body", and "beauty" reveal that beauty is different from each program. The fashionably styled program features a face with a pointy 
nose and a spotless skin, a hiatus shar'i program featuring a skin that looks natural and natural, a veil featured in the eyes. All three are equally high body and slim with pose and choice of clothing that is used [16].

Wolf states that the myth of beauty contrasts the new freedom that women gain in their lives, by reversing the social boundaries directly on the body and the face of women alone. The myth of beauty offers to fake choice women.

This body management is then provided in the form of treatments that link beauty ideology, women are politicized in body care products. The subjection of women with veils to their bodies is done with the use of makeup used in such a way as to look beautiful but not excessive, using skin care products for bright and healthy skin, the use of hijab in accordance with the character of each self and the understanding of religion that is believed and the use of clothing combined with hijab in order to keep it look fashionable and attractive. The use of clothing is also arranged so that it can still display the ideal body that grows in the community, which is tall and slender. So that the impression of pious and interesting can be seen from the veiled women [16].

\section{CONCLUSION}

Referring ideological knowledge to the female body, which is assumed that their beauty is one of the elements that always need improvement. Women are veiled as if they are competing as attractive as possible in accordance with their own characteristics. Hijab which can be a symbol of liberation from beauty standards now is not separated from the attributes of beauty. They use cosmetics to highlight certain parts of the face as well as perform body care activities to look beautiful and attractive, with indicators look natural or not too much. Beauty is seen from the physical as a face with a beautiful, well-groomed white, and attractive appearance with a fashion that closes the aurat but trendy into a beauty ideology in women with hijab. The dominant beauty ideology is still centered on physical appearance. Discipline in the form of body discipline is done and shown through posture, skin, and makeup.

The beautiful myth is also indirectly perpetuated by women, because it is desired by women. In the movement of a beautiful cultural circulation myth is represented through a product for women, then consumed by women themselves who in the regulation follow the wishes and needs of women. Beauty is seen from the physical as a face with a beautiful, well-groomed white, and attractive appearance with a fashion that closes the aurat but trendy into a beauty ideology in women with hijab. In the end, the veiled women still cannot be separated from the beauty myths. Religious norms that are compromised with modernity and commercial do not dispel the myths.

\section{REFERENCES}

[1] P. I. Indriyani, "Indriyani, P. I. 2016. Komodifikasi Hijab dalam Iklan Sampo Sunsilk Clean and Fresh di Televisi.," UNIVERSITAS ISLAM NEGERI SUNAN KALIJAGA YOGYAKARTA, 2016.

[2] Y. Ramaniya, "Pergeseran Wacana tentang Konstruksi Kecantikan Studi pada Klinik Kecantikan Natasha Skin Clinic Center," Gadjah Mada University, 2015.

[3] D. Farhad, "Hijab Fashion Industries ' Unveiled' By: Danybell Farhad."

[4] A. Siraj, "Meanings of modesty and the hijab amongst Muslim women in Glasgow, Scotland," Gender, Place Cult., vol. 18, no. 6, pp. 716-731, 2011

[5] A. R. Beta, "Hijabers: How young urban muslim women redefine themselves in Indonesia," Int. Commun. Gaz., vol. 76, no. 4-5, pp. 377-389, 2014

[6] N. Hassim, "Hijab and the Malay-Muslim Woman in Media," Procedia - Soc. Behav. Sci., vol. 155, pp. 428-433, Nov. 2014.

M. Woldesemait, "Unfolding the Modern Hijab: From the Colonial Veil to Pious Fashion," 2013.

[8] S. Ali, F. Halim, and N. B. Ahmad, "Beauty Premium and Hala Cosmetics Industry," J. Mark. Manag. Consum. Behav., vol. 1, no. 4, pp. 52-63, 2016

[9] O. I. Fardiana, "Mitos Kecantikan Perempuan Muslim(Studi Diskursif Dalam Blog Fashion Muslim),” 2014.

[10] Y. Hermawati, A. Piyatna, and M. Adji, "Instagram dan mitos kecantikan perempuan muslim,” vol. 2, no. November, 2016.

[11] Rusli Muchtar, "Fiqh Jilbab dan Wacana Tubuh Perempuan," Musawa, vol. 1, no. 1, pp. 21-34, 2009.

[12] E. D. Jayanti, "Eksploitasi hijab dalam iklan produk muslimahkosmetik sophie paris di televisi," 2014.

[13] Budiastuti, Jilbab dalam Perspektif Sosiologi: Studi Pemaknaan Jilbab di Lingkungan Fakultas Hukum Universitas Muhammadiyah Jakarta, 2012

[14] H. Q. Mayaningrum and A. Triyono, "Komodifikasi Hijab Dalam Iklan Kosmetik Sophie Paris Versi Natural \& Halal" Di Televisi," Channel, vol. 4, no. 2, pp. 207-226, 2016.

[15] A. King, "The Prisoner of Gender: Foucault and the Disciplining of the Female Body," vol. 5, no. 2, p. 4, 2004.

[16] N. B. Dina, "Representasi Kecantikan Perempuan Berhijab pada Akun Instagram Selebgram Hijab (Analisis Wacana Sara Mills)," Commonline Dep. Komun. FISIP Univ. Diponegoro., vol. 4, 2015. 